\title{
The Yuan and Shanghai Pilot Free Trade Zone
}

\author{
Daqing Yao \\ Shanghai Academy of Social Sciences, Shanghai, China \\ John Whalley \\ University of Western Ontario, London, Canada
}

\begin{abstract}
In this paper, we present evidence as to the effects of the China (Shanghai) Pilot Free Trade Zone on China's capital controls which was initiated in September, 2013. It was a trial to introduce a combination of floating exchange rate and capital account liberalization into China's macro policy mix. We employ three methods to test the China (Shanghai) Pilot Free Trade Zone's impact on capital controls: price spread tests between Chinese Yuan in Hong Kong and Chinese Yuan, Renminbi yield gaps between onshore and offshore Renminbi markets, and Granger causalities in China's money supply and foreign interest rates. All these tests give consistent results suggesting that the impact of China's capital controls is weaker since the China (Shanghai) Pilot Free Trade Zone.
\end{abstract}

JEL Classifications: F32, F36, F38

Keywords: Evaluation, Effect, Shanghai, Free Trade Zone

\footnotetext{
* Corresponding Author: John Whalley; Department of Economics, University of Western Ontario, 1151 Richmond Street, London, Ontario, N6A 5C2, Canada; Tel: +1 5196613509, Fax: +1 5196613064, E-mail: jwhalley@uwo.ca. Co-Author: Daqing Yao; Institute of World Economy, Shanghai Academy of Social Sciences, 622 Huaihaizhong Road, Shanghai, 200020, China; Tel: +86 2153060606; Fax: +86 2153063814, E-mail: yaodaqing@sass.org.cn.
}

Acknowledgements: We are grateful to the Ontario Research Fund (ORF) and Centre for International Governance Innovation (CIGI) for financial support. The first author also thanks to the Chinese National Social Science Foundation for financial support with the project No. 15BJL076 


\section{Introduction}

The adoption of the China (Shanghai) Pilot Free Trade Zone (SPFTZ) at the end of September, 2013 is part of an ambitious trial for a new round of Chinese reform and opening up, with stress on capital liberalization. ${ }^{1}$ After one year's operation, we offer an evaluation of the impact of the SPFTZ on China's capital controls.

China is one of the largest economy in the world which still maintains relatively rigorous capital controls. According to the capital liberalization criteria of the International Monetary Fund (IMF), China has controls on all thirteen sub-items of capital transactions (IMF 2014, p. 81). Although capital controls are normal in developing countries which lack foreign exchange, it may seem strange for China which has a large share of total foreign reserves in the world. Capital controls have also been an obstacle to the internationalization of the Renminbi (RMB), but they also serve as a seawall for the domestic financial market.

China maintains capital controls for both state security and policy independence. The Asian financial crisis in 1990s taught China that capital liberalization can be dangerous without enough preparation. According to the Impossible Trinity, which is a trilemma in international economics, it is impossible to have all three of the following at the same time: A fixed exchange rate, free capital movement, and an independent monetary policy. To the Chinese government which insists on independence in foreign policies, surrendering monetary policy to others is unimaginable. Therefore China must choose between a fixed exchange rate and capital liberalization. In the past, China chose the former: a pegged (and often under-valued) RMB, with rigorous capital controls, especially on capital outflows and hot money inflows.

Such a policy combination induces export orientation and foreign capital competition, and fits well with a catching up strategy for China. China's Gross Domestic Product (GDP) more than tripled in merely twelve years after she joined the World Trade Organization (WTO) in 2001, reflecting an average annual growth rate of $10.09 \%$. As a result, China's foreign reserves increased sharply. The value of China's total reserves in 2001 was 220 billion current US dollars, and by 2013 they had increased to 3.88 trillion as shown in Figure 1, which is more than triple the amount of Japan's 1.27 trillion, the second largest reserve.

\footnotetext{
${ }^{1}$ We give a detailed introduction of the SPFTZ in a separate paper, Yao and Whalley (2015).
} 
Figure 1. Trade balance and foreign reserve of China

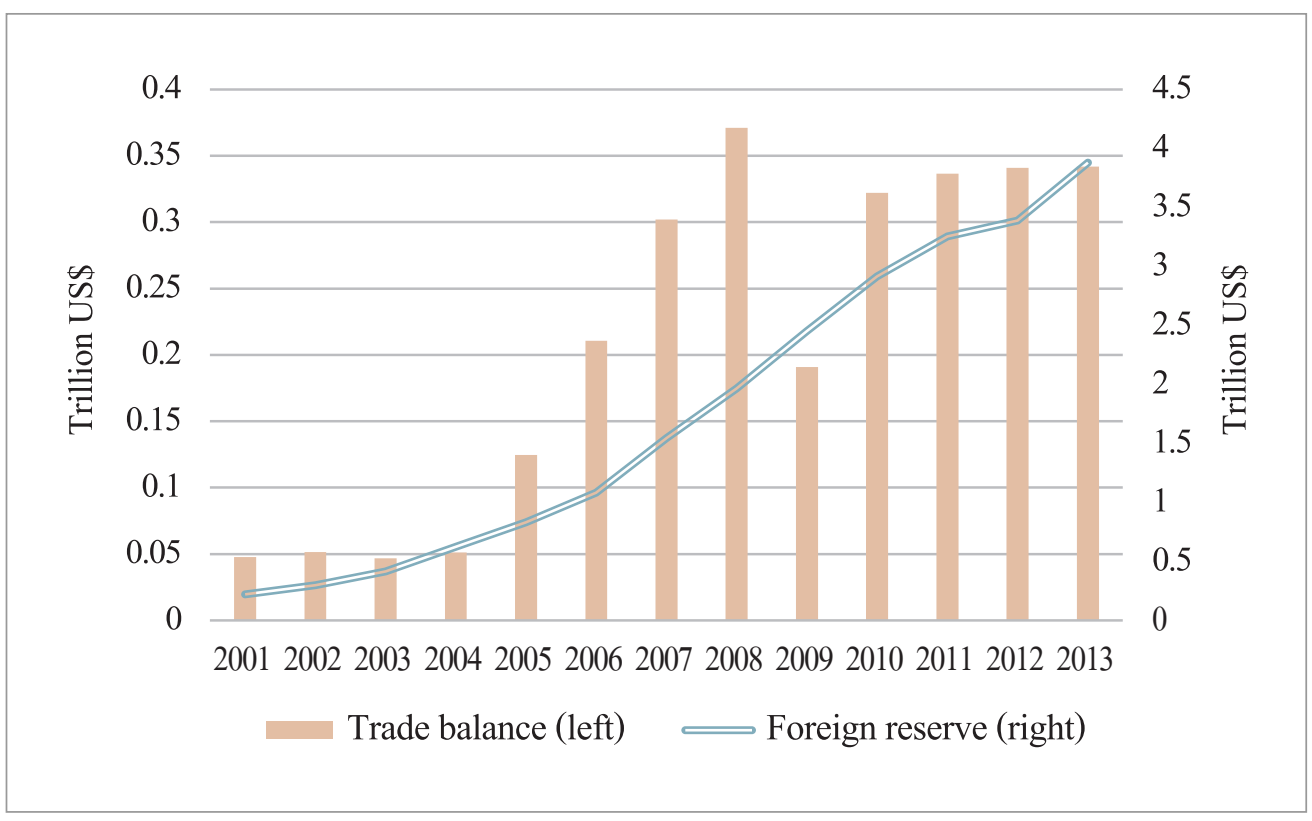

(Source) World Development Indicators database.

But the accumulation of foreign reserve while maintaining a stable RMB has its own price. The balance sheet of the People's Bank of China (PBoC), China's central bank, must be balanced. As the assets increased quickly with the accumulation of reserves, the PBoC had to increase its debt equally, which meant injecting more money into the economy. The rate of increase of China's M0 has been at about 10\% in recent years, with an M2 increase of nearly 15\%, shown in Figure 2. At the end of September, 2014, the M2 of China was 120,205 billion RMB. ${ }^{2}$ By comparison, the M2 of the US at the same time was 11,473 billion US dollars. This means that although China's GDP is only one-third of that of the US, China's money supply is about two-thirds more, which contributes to the inflation and asset price booms in recent years.

${ }^{2} \mathrm{RMB}$ is the abbreviation of China's currency, the Renminbi. 


\section{Figure 2. Money supply of China}

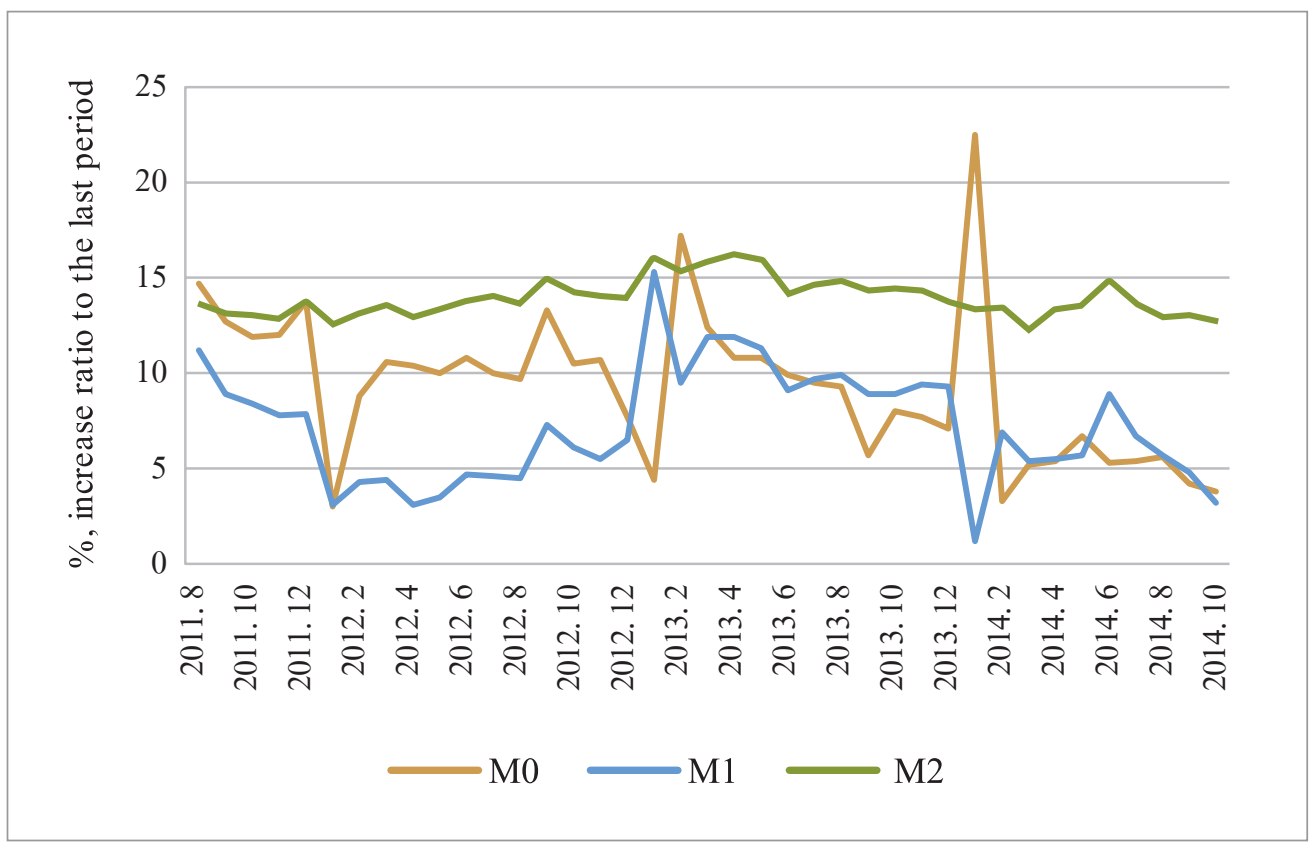

(Source) International Monetary Fund database.

Because of the problems induced by the fixed exchange rate and capital controls, the Chinese government now seeks to adjust to a combination of a relatively open capital account and an enlarged degree of float in the RMB, while maintaining her policy independence. From September 1998 to June 2005, the exchange rate of RMB to US dollar was pegged at 8.27 for seven years. Since July 2005, however, China has allowed RMB crawling appreciation to a basket of currencies, and the floating band has been enlarged to $\pm 2 \%$. Capital controls have been loosened gradually, with an RMB internationalization policy in place from July 2009. This process continues with the SPFTZ.

Launched on September 29, 2013, the SPFTZ is more than a traditional free trade area, and more a trial zone for China's new opening and reform strategy. It is a unilateral set of measures and procedures relating to a small area in Shanghai, which has promised liberalization on capital account and trade facilitation as its main objectives. After one year's operation, the SPFTZ has already met several important policy objectives in the four following areas.

First is reforming the legal and regulatory system. The $12^{\text {th }}$ National Congress 
Standing Committee authorized the State Council to temporarily adjust certain administrative examination and approval requirements under three foreign capital enterprise laws in the SPFTZ. The regulatory environment for supervision and tax has also been improved. In the SPFTZ, a foreign investment project is no longer required to apply for confirmation from the Chinese government unless it involves the negative list.

Second is adopting a negative list management for foreign investment. On September 30, 2013, the Shanghai municipal government published special management recommendations for foreign investment in SPFTZ (2013 version), usually called the negative list. The 2014 version negative list decreased the 190 regulations to 139 .

Third is improving trade facilitations. The Customs, Inspection, and Quarantine Bureau, and the Maritime Affairs Administration of SPFTZ have provided more than 60 new policies on trade facilitation. The basic policy is first-line decontrolled, second-line controlled safely and efficiently, and free movement within the FTZ. The so-called firstline refers to the border, and the second-line refers to the domestic market boundary.

The fourth is the financial innovations. Four financial supervisors, namely the PBoC, and three regulatory commissions on banking, securities, and insurance, have adopted 51 new regulating methods to build a new financial architecture in the SPFTZ, with the essential policy being the free trade accounts. Financial institutions in Shanghai can build a Free Trade Accounting Unit (FTU), which is separate from the institution's other accounting system. The accounts are called free trade accounts, in which both domestic currency RMB and foreign currencies are regulated under the same rules.

We give a detailed introduction of the SPFTZ and its policy innovation in Yao and Whalley (2015a). In this paper, we focus on the effect of the SPFTZ on China's capital control. The organization of this paper proceeds as follows. After discussing the cross border capital flows since the SPFTZ in Section II, we employ three methods to test the SPFTZ's impact on capital controls in Section III to Section V: price spread tests between Chinese Yuan in Hong Kong (CNH) and Chinese Yuan (CNY), RMB yield gaps between onshore and offshore RMB markets, and Granger causalities in China's money supply and foreign interest rates. The choice of these three methods is following the literatures in this field and the data availability for China's market. Section VI presents the concluding remarks. 


\section{Cross-Border Capital Flows}

\section{A. China's capital flows}

We begin with the effects of the SPFTZ on capital flows. Although the definition of capital flows is clear, there are some difficulties in computing the cross-border capital flows for China. Ma (2008) defines capital flows as the sum of debit and credit flows on China's balance of payments, excluding errors and omissions. According to his calculation, gross capital account flows represented 40\% of China's Gross Domestic Product (GDP) in 2005. Ma (2008) acknowledges that such a definition is likely to underestimate capital flows because some capital flows take the form of current account transactions in order to avoid official restrictions, and most reported bank-related gross flows represent changes between two dates and do not capture any intervening gross flows. In theory, we can compute the net capital flow in a period by comparing the capital stock change between the beginning and the end of that period. The actual capital flow may be larger than this if there is capital inflow and outflow in such period. ${ }^{3}$

We compute China's capital flows for a more recent year following Ma (2008). These data are calculated from the Balance of Payments database of the IMF, ${ }^{4}$ and capital flows are computed as the change between two years. As listed in Table 1, both the capital flows in and out of China have increased rapidly since 2009.

\footnotetext{
${ }^{3}$ See Ma (2008), p.105, footnote 2.

${ }^{4}$ The raw data can be downloaded from http://elibrary-data.imf.org/DataReport.aspx?c=20303469.
} 
Table 1. Capital flows in and out of China

(US dollar, billions)

\begin{tabular}{|c|c|c|c|c|c|}
\hline & $\mathbf{2 0 0 9}$ & $\mathbf{2 0 1 0}$ & $\mathbf{2 0 1 1}$ & $\mathbf{2 0 1 2}$ & $\mathbf{2 0 1 3}$ \\
\hline Assets (Capital outflow) & $\mathbf{4 8 0 . 2 1}$ & $\mathbf{6 8 1 . 9 6}$ & $\mathbf{6 1 5 . 6 4}$ & $\mathbf{4 7 8 . 6 6}$ & $\mathbf{7 2 3 . 6 7}$ \\
\hline Direct investment & 60.06 & 71.46 & 107.57 & 107.16 & 77.15 \\
\hline Portfolio investment & -9.74 & 14.34 & -52.70 & 36.19 & 17.92 \\
\hline Other investment & -57.09 & 135.15 & 219.17 & 203.23 & 136.08 \\
\hline Reserve assets & 486.98 & 461.01 & 341.60 & 132.08 & 492.52 \\
\hline Liabilities (Capital inflow) & $\mathbf{4 8 3 . 1 5}$ & $\mathbf{4 8 4 . 4 4}$ & $\mathbf{6 1 5 . 2 6}$ & $\mathbf{3 0 0 . 6 0}$ & $\mathbf{6 1 8 . 5 5}$ \\
\hline Direct investment & 399.25 & 254.83 & 337.30 & 161.12 & 279.44 \\
\hline Portfolio investment & 22.24 & 33.89 & 24.62 & 87.60 & 50.73 \\
\hline Other investment & 61.66 & 195.71 & 253.33 & 51.88 & 288.37 \\
\hline
\end{tabular}

(Notes) (i) Reserve asset is an item in the financial accounts, whose increase means that the central bank is buying foreign assets and capital is flowing out. See IMF: Balance of payments and international investment position manual (2009), the 6th edition, p.130.

(ii) There is another item of financial account, the Financial derivatives (other than reserves) and Employee stock options, which is omitted here because the amount for China is very small.

(Source) Author's computations based on the IMF database.

The Institute of International Finance (IIF) publishes biannual reports entitled Capital Flows to Emerging Markets, which depict China's capital flows directly, but the data are restricted to its members. Figure 3 replicates the IIF's report in October, 2014. 


\section{Figure 3. Direct equity investment flows of China}

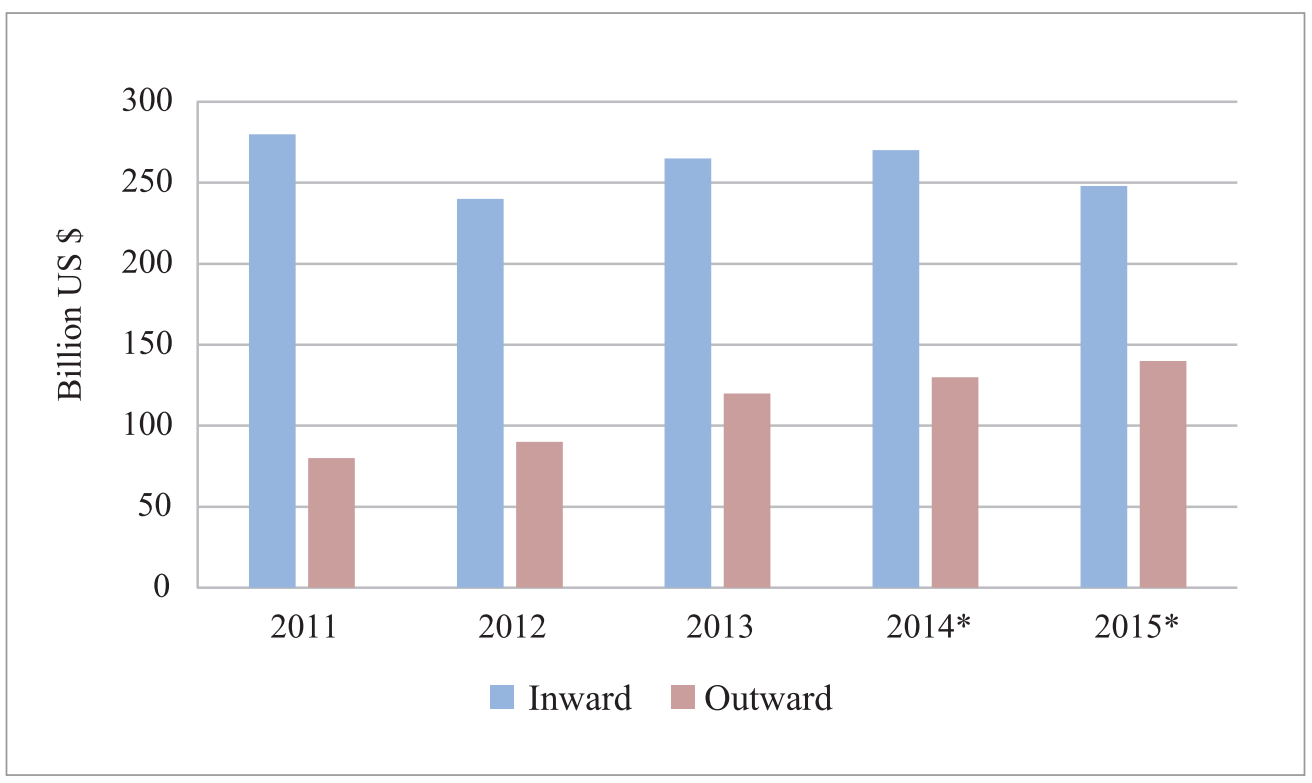

(Note) * show the projections.

(Source) The IIF Capital flows to emerging markets. October 2, 2014, p. 27.

Although different data sources can vary substantively, we can see that capital flows have increased during the previous years. This suggests that the Chinese economy has become more integrated into the global economy and hence more exposed to the fluctuation of international markets. In particular, the rapid increase of outflow capital points to the use of more opportunities to evade capital controls, which questions the effectiveness of capital controls.

\section{B. China's hot money flows}

Another way to evaluate the impact of capital controls is to calculate hot money flows. There is no formal definition of hot money, but the term is most commonly used in financial markets to refer to the flow of funds or capital from one country to another in order to earn a short-term profit on interest rate differences and/or anticipated exchange rate shifts (Martin and Morrison 2008). These speculative capital flows are called hot money because they can move very quickly in and out of markets, potentially leading to 
market instability.

Martin and Morrison (2008) point out that because hot money flows quickly and is poorly monitored, there is no well-defined, direct method for estimating the amount of hot money flowing into a country during certain period of time. One common way of approximating the flow of hot money is to subtract a nation's trade surplus or deficit and its net flow of Foreign Direct Investment (FDI) from the change in the nation's foreign reserves.

Here, we define hot money as the difference between capital inflows and the increase of foreign reserves. Because of data availability, we only consider four types of capital inflows: trade surplus, FDI net inflow, investment income abroad, and public finance abroad. In theory, all foreign exchanges from international transactions must be forwarded through banks to the State Administration of Foreign Exchange (SAFE) and be exchanged as RMB. Therefore, if the capital inflow is larger than the increase of reserves, there should be a hot money outflow which cannot be tracked by official records. Thus:

\section{Hot Money Net Inflow = Increase of Reserve - Trade Surplus - FDI Net Inflow - Investment Income Abroad - Public Finance Abroad}

We have thus calculated the hot money inflows of China between 2006 and 2012, and reported them in Table 2. We can see that the hot money fluctuated dramatically during this period. In the beginning and the end there is hot money outflow, while in the middle years there is hot money inflow. In the year of 2012, the outflow of hot money skyrocketed to 326.7 billion US dollars. The hot money volume itself may be more relevant to the market expectation of the Chinese economy and the appreciation of RMB, but such a huge increase can also be regarded as indicating that the impact of capital controls is weakening. 
Table 2. Hot money inflows of China

(US dollar, billions)

\begin{tabular}{|c|c|c|c|c|c|c|}
\hline Year & $\begin{array}{c}\text { Trade } \\
\text { Surplus }\end{array}$ & $\begin{array}{c}\text { FDI Net } \\
\text { Inflow }\end{array}$ & $\begin{array}{c}\text { Investment } \\
\text { Income } \\
\text { Abroad }\end{array}$ & $\begin{array}{c}\text { Public } \\
\text { Finance } \\
\text { Abroad }\end{array}$ & $\begin{array}{c}\text { Increase of } \\
\text { Reserve }\end{array}$ & $\begin{array}{c}\text { Hot Money } \\
\text { Net Inflow }\end{array}$ \\
\hline 2006 & 177.5 & 45.4 & 50.2 & 39.4 & 285.3 & -27.2 \\
\hline 2007 & 264.3 & 49.9 & 76.6 & 12.7 & 460.9 & 57.4 \\
\hline 2008 & 298.1 & 50.5 & 102.7 & 4.6 & 478.3 & 22.4 \\
\hline 2009 & 195.7 & 42.2 & 99.0 & 15.7 & 382.1 & 29.5 \\
\hline 2010 & 181.5 & 46.7 & 128.8 & 35.4 & 469.6 & 77.1 \\
\hline 2011 & 155.1 & 55.9 & 128.0 & 11.3 & 384.8 & 34.4 \\
\hline 2012 & 231.1 & 34.5 & 143.8 & 16.0 & 98.7 & -326.7 \\
\hline
\end{tabular}

(Source) Authors' computation based on the DZH Database. ${ }^{5}$

\section{Capital flows since the SPFTZ}

Since the start of the SPFTZ on September 29, 2013, the capital flows of China have increased. Table 3 is based on the Balance of Payments of China in recent quarters. ${ }^{6}$ Before the start of the SPFTZ, the inflow and outflow volumes were about 300 400 billion US dollars. From the fourth quarter of 2013, the capital outflow increased gradually to 620 billion US dollars. The capital inflow shows a more rapid increase, from 402 billion to 636 billion US dollars, which is more than a half increase in three quarters.

\footnotetext{
${ }^{5}$ The DZH Database is a product of Shanghai DZH Company, which provides Chinese financial data and data analysis to the investors all over the world. The authors are authorized to use the DZH Database in this research.

${ }^{6}$ The raw data can be downloaded from the official website of the SAFE, http://www.safe.gov.cn.
} 
Table 3. The capital flow of China since the China (Shanghai)

Pilot Free Trade Zone

(US dollar, billions)

\begin{tabular}{|c|c|c|c|c|c|c|}
\hline & $\mathbf{2 0 1 3 Q 1}$ & $\mathbf{2 0 1 3 Q 2}$ & $\mathbf{2 0 1 3 Q 3}$ & $\mathbf{2 0 1 3 Q 4}$ & $\mathbf{2 0 1 4 Q 1}$ & $\mathbf{2 0 1 4 Q 2}$ \\
\hline Assets (Capital Outflow) & $\mathbf{4 5 7 . 3 0}$ & $\mathbf{2 2 7 . 6 5}$ & $\mathbf{4 8 2 . 5 0}$ & $\mathbf{5 5 5 . 1 9}$ & $\mathbf{6 0 2 . 6 4}$ & $\mathbf{6 2 0 . 9 5}$ \\
\hline Direct Investment & 67.89 & 79.61 & 73.99 & 126.36 & 93.20 & 90.56 \\
\hline Portfolio Investment & 22.44 & 22.95 & 17.93 & 40.83 & 40.33 & 26.20 \\
\hline Other Investments & 366.98 & 125.09 & 390.58 & 388.01 & 469.12 & 504.19 \\
\hline Reserve Assets & 157.08 & 47.07 & 97.57 & 130.99 & 125.90 & 22.75 \\
\hline Liabilities (Capital inflow) & $\mathbf{3 6 8 . 8 1}$ & $\mathbf{1 9 9 . 9 2}$ & $\mathbf{4 0 2 . 4 9}$ & $\mathbf{4 2 8 . 2 8}$ & $\mathbf{5 0 8 . 8 3}$ & $\mathbf{6 3 6 . 5 6}$ \\
\hline Direct Investment & 35.96 & 33.99 & 39.83 & 53.10 & 39.53 & 51.24 \\
\hline Portfolio Investment & 8.36 & 12.98 & 7.90 & 14.36 & 17.99 & 11.65 \\
\hline Other Investments* & 324.48 & 152.95 & 354.76 & 360.83 & 451.31 & 573.67 \\
\hline
\end{tabular}

(Notes) These other investment figures may seem too big, but a relatively large Other Investments is normal in China's Balance of Payments. Some analysts think that there are hidden hot money flows in this account. (Source) Authors' computation based on the SAFE Database.

\section{Price Spread Test}

We have shown that the capital flows in and out of China have increased in recent years, and this increase has speeded up since the start of the SPFTZ. However, the increase of capital flows cannot itself be treated as a proxy for lowered capital control impact. If every flow must acquire a permit from the government, volume increases can simply indicate a busy government. A more direct test of capital control impact of the SPFTZ is to check whether there exist substantial cross-border arbitrage opportunities for a considerable period of time after the introduction of the SPFTZ. According to the law of one price, if capital flows were free, there should be no significant and persistent price differences for the same financial assets across the border of China. As Ma (2008) pointed out, when price and flow measures are consistent with each other, one may arrive at an easy conclusion regarding capital mobility, but when they point at different 
directions, price evidence should be given more weight. In the following, we conduct price tests for the impact of China's capital controls since the SPFTZ.

\section{A. The offshore exchange market and the Chinese Yuan in Hong Kong}

We already reported that the start of the SPFTZ has induced more capital flows in and out of China. Therefore, the assessment of its impact on capital controls can be achieved by studying the price spread between Chinese Yuan (CNY) and Chinese Yuan in Hong Kong (CNH). As pointed out by Chen and Whalley (2013), there is currently a dual system of RMB markets. The CNY is the onshore exchange rate of RMB, while the $\mathrm{CNH}$ is the offshore exchange rate of RMB in Hong Kong, officially called Hong Kong Special Administrative Region (HKSAR). If capital controls have been loosened, this price spread should show a tendency to diminish since the founding of the SPFTZ.

\section{B. Data}

We can obtain the $\mathrm{CNH}$ daily exchange rate data from both Wind Database and Bloomberg. The time period is from August 31, 2012 to September 30, 2014, with September 29, 2013 on which the SPFTZ was founded in the middle of the interval. The source of CNY daily exchange rate data is the Federal Reserve Economic Data (FRED), the Economic Data by the United States' Federal Reserve Bank of St. Louis. Although the People's Bank of China also provides the daily CNY data, we use the data from FRED because it is more convenient when comparing with other international data, e.g., the exchange rate of euro.

The use of daily data brings a problem of time gap and mismatch in transaction dates. All the financial transactions are stopped during the weekends and holidays. While the weekend's data are the same all over the world, the holiday dates can vary significantly. In the FRED data, there is no transaction on the US federal holidays including New Year's Day, Martin Luther King, Jr. Day, President's Day, Memorial Day, Independence Day, Labor's Day, Columbus Day, Veterans Day, Thanksgiving, and Christmas. The $\mathrm{CNH}$ transaction takes place in Hong Kong, where the holidays (Chinese, Western, and local holidays) are even more complex. Therefore, the $\mathrm{CNH}$ transaction stops on Lunar 
New Year's Day, Ching Ming Festival, Buddha's Birthday, Tuen Ng Festival, HKSAR Establishment Day, Chinese Mid-Autumn Day, Chinese National Day, Chung Yeung Festival, and Christmas. In order to make data comparable, all such mismatched data are deleted.

Altogether we have 493 matched transaction days and 493 pairs of CNY and $\mathrm{CNH}$ exchange rate data. The price spread of $\mathrm{CNY}$ to $\mathrm{CNH}$ can be easily computed, represented in Figure 4.

\section{Figure 4. The price spread of $\mathrm{CNY}$ and $\mathrm{CNH}$}

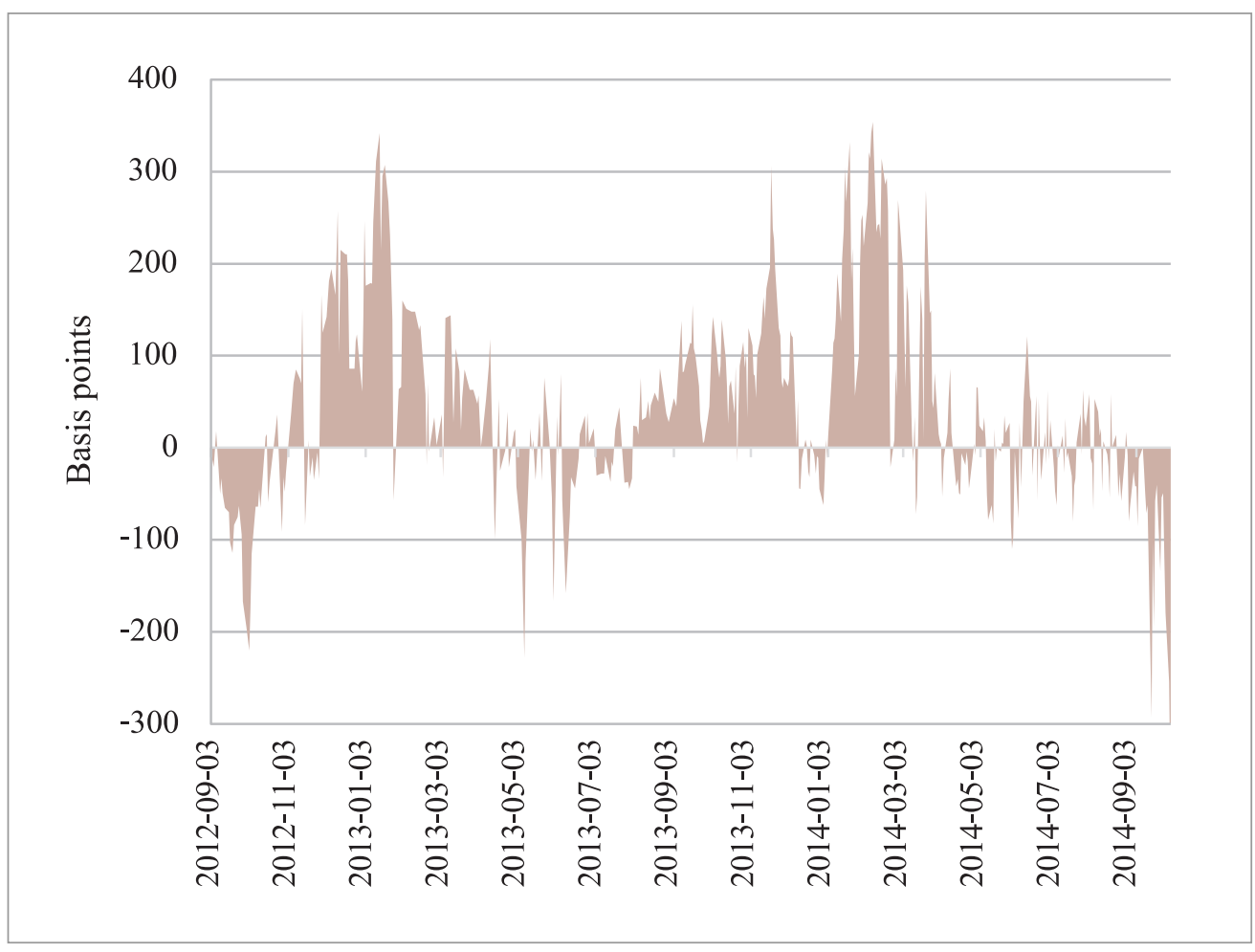

(Source) Authors' computation based on the Wind, Federal Reserve Economic Data, and Bloomberg Databases.

From Figure 4, we can see that, generally speaking, the start of the SPFTZ has brought the price spread of CNY and CNH closer. In the year before the SPFTZ, the price spread reached 300 basis points (BP, 1 base point equals 0.0001 ). However, since the SPFTZ, especially since later March, the price spread seldom reached 100 base points. Considering that the financial liberal policy of supporting RMB cross-border use 
in the SPFTZ was declared on February 21, 2014, the price spread data fit this policy quite well.

There are several periods when the price spread is relatively high, most obviously from early January to mid-March, 2014. It emphasizes that we cannot explain the movement of that price spread only by the financial policy in SPFTZ. In order to give a reasonable explanation of such disparities, we need to consider other elements determining the exchange rates of $\mathrm{CNY}$ and $\mathrm{CNH}$.

\section{The relationship between $\mathrm{CNY}$ and $\mathrm{CNH}$}

Since Chinese Yuan (CNY) and Chinese Yuan in Hong Kong (CNH) are essentially the prices of the same currency, the yuan, the fundamental elements such as exports, imports, price level, and money supply are the same. This is the reason why the two prices are very similar most of the time. In fact, their correlation in the period of study is 0.9901 .

As to the short term elements, the CNY is the price on the domestic foreign exchange market, and there will be intervention by the Chinese authorities, usually the People's Bank of China. After the end of each transaction day, the People's Bank of China will decree a mid-price of $\mathrm{CNY}$ according to the closing prices of RMB to other currencies on that day. The Center for Foreign Exchange Transactions of China is authorized to publish this mid-price on the next transaction day, and all the brokers in the foreign exchange market must offer a price within designated limits of this mid-price. The limit was $0.3 \%$ from the reform of exchange rate mechanism in July 2005 , enlarged to $0.5 \%$ in May 2007, enlarged again to 1\% in April 2012, and currently is no more than 2\%, all in both directions. Although the limit is enlarged steadily, considering that the main brokers in the market are the state-controlled banks, the $\mathrm{CNY}$ is more a planning price than a market price.

Because the offshore CNH market is much smaller than the onshore CNY market, it is not surprising that for most of the time the $\mathrm{CNH}$ shows the same movement as the CNY. On the other hand, since there are less financial controls in HKSAR, the CNH is more sensitive to the changes in international capital markets. This can be seen by analyzing the movements of the US dollar. 
Figure 5. The trends of USD and CNY

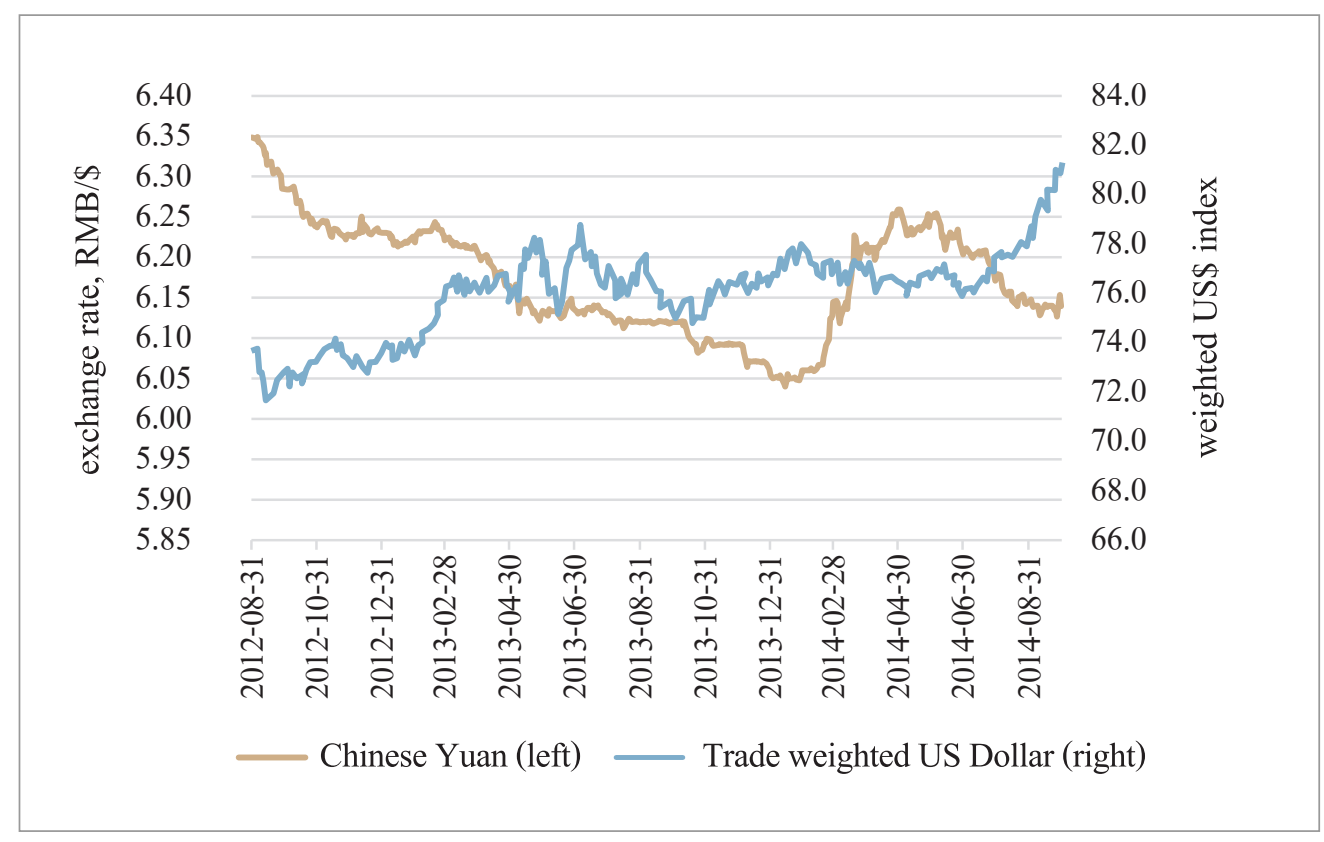

(Source) Database of the Federal Reserve Economic Data.

Figure 5 depicts the trend of trade weighted USD index and CNY in the past two years. We can basically see that the two series are negatively correlated. Their correlation is -0.5821 but in the period from mid-January to early April, 2014, while the USD index kept stable at around 77.0, the CNY depreciated quickly from 6.06 to 6.24, with a loss in value of more than $3 \%$. This period corresponds to the relatively large positive price spread between CNY and CNH. Similarly, from mid-September of 2014, the USD index has appreciated from 78.5 to 81.3 , but the CNY stayed at about 6.14. This corresponds to the negative price spread between $\mathrm{CNY}$ and $\mathrm{CNH}$.

As Chen and Whalley (2013) point out, the spread between CNH and CNY represents the benefits of effective convertibility through market transactions. We can draw the conclusion that, although $\mathrm{CNH}$ show the same movements along with $\mathrm{CNY}$ most of the time, there will be a relatively larger price difference between them if CNY moves in the opposite direction to the USD. The underlying policy explanations for these two periods are as follows. From mid-January to early April, 2014, Chinese authorities manipulated the CNY to depreciate, which did not accord with the international financial market, whereas the CNH value is higher than CNY. From later September, 2014, 
Chinese authorities did not let the CNY depreciate as the US dollar appreciated, which made the CNH value lower than the CNY's.

Except for these two periods, the price spread between CNH and CNY is small since the SPFTZ started. The market can operate more efficiently. This is evidence that the financial liberalization of China has made progress since the SPFTZ, and the effectiveness of capital controls is weaker.

\section{The Effects on China's Capital Controls}

Although the price spread test is illuminating, we can conduct a formal price test by analyzing the combination of onshore RMB interest rates, offshore US dollar interest rates and Non-Deliverable Forward (NDF) exchange rates. The NDF is defined as a cash-settled, short-term forward contract on a thinly traded or non-convertible foreign currency, where the profit or loss at the time of the settlement date is calculated by taking the difference between the agreed upon exchange rate and the spot rate at the time of the settlement, for an agreed upon notional amount of funds. If the differences between onshore RMB interest rates and those implied by the offshore NDFs in conjunction with US dollar Libor show a tendency to diminish, it will be a direct support for the position that the impact of capital controls is lower after the SPFTZ.

\section{A. Theoretical foundation}

The theoretical base for such a price test is Interest Rate Parity, which requires that the revenue of the same money should be equal in different currencies if there is no capital control. Therefore, the forward exchange rate of the home currency is linked by arbitrage to its spot rate and the dollar offshore interest rate through the covered interest parity condition:

$$
F_{t}=\frac{S_{t}\left(1+r_{t}\right)}{1+r_{t}^{\$}}
$$


Here, the $F_{t}$ is the forward exchange rate of RMB, $S_{t}$ is the spot rate of RMB, $r_{t}$ is the interest rate of $\mathrm{RMB}$, and $r_{t}^{\$}$ is the offshore interest rate of dollar.

However, because there are capital controls in mainland China, non-residents may not have full access to the onshore credit market. Since there is no capital control in HKSAR, the NDF version of covered interest parity should hold:

$$
N D F_{t}=\frac{S_{t}\left(1+i_{t}\right)}{1+r_{t}^{\$}}
$$

In this equation, $i_{t}$ is the NDF-implied yield of RMB offshore:

$$
i_{t}=\frac{N D F_{t}}{S_{t}}\left(1+r_{t}^{\$}\right)
$$

There can be a significant difference between $r_{t}$ and $i_{t}$ if capital controls are highly effective. Therefore, the onshore and offshore interest rate spread $\left(r_{t}-i_{t}\right)$ is an indication of the impact of cross-border capital controls.

\section{B. Data}

In order to perform the price test, we need to carefully choose the financial instruments for their maturity, credit, and liquidity. If the instruments share the same maturity, issued by the same private parties, and enjoy the same liquidity, the price test can work better. We choose Shibor, the Shanghai Interbank Offered Rate, as the domestic interest rate. Shibor is computed by the interbank offer rates of 18 main banks in China, and is regarded as the benchmark rate in the money market. The Shibor rates include overnight, one week, two weeks, one month, three months, six months, nine months, and one year. Shibor rates shorter than three months are mainly determined by supply and demand in the money market, while those equal and longer than three months are determined mainly by expectation of future interest rates.

To compute the implied interest rate in the offshore market, we need the spot and NDF exchange rates of RMB, as well as the US dollar offshore interest rates. Spot exchange rates of RMB are easy to obtain, and the Libor rates are suitable for dollar offshore interest rates. As to the NDF exchange rates, there are currently four NDF 
markets for the dollar-RMB transactions, namely New York, London, Hong Kong, and Singapore. We choose the NDF rates in Hong Kong as it is the largest NDF market.

In order to minimize the mismatch among different data sources, all the data are drawn from the DZH database. ${ }^{7}$ The data period is from October 8, 2006, the beginning date of Shibor data, to the latest trade date when we executed this study, November 6, 2014.

\section{Figure 6. The yield gap between onshore and offshore RMB}

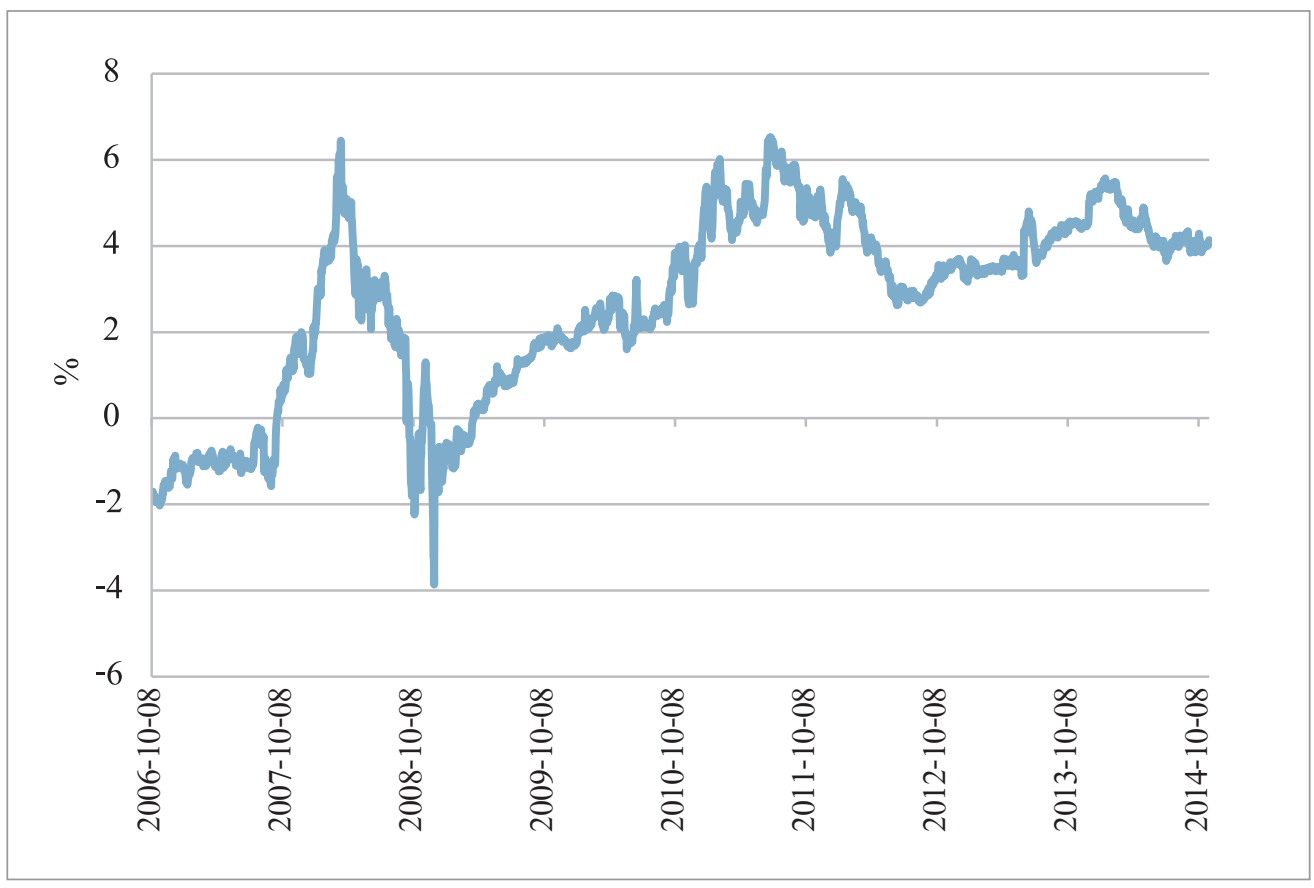

(Source) Authors' computation based on the DZH Database.

Figure 6 shows the yield gap between onshore and offshore RMB, which is computed by subtracting the implied offshore rates from domestic Shibor rates. If compared with the study of Ma (2008) for the period 1999 to 2006, we find that the yield gap seldom reached $6 \%$ after 2006 , while it often exceeded $8 \%$ before that. This is consistent with Ma (2008) who stated that the yield gap has narrowed since the July 2005 policy change, when the PBoC announced that RMB would peg to a basket of currencies rather than the US dollar and can float according to market supply and demand.

\footnotetext{
${ }^{7}$ The DZH Database is a product of Shanghai DZH Company, which provides Chinese financial data and data analysis to the investors all over the world. The authors are authorized to use the DZH Database in this research.
} 
The evolution of RMB yield gaps in Figure 6 moves through several phases. The first is from September 2007 to the end of 2008, when the gaps peaked in March 2008. The second phase is from early 2009 to the end of 2011, when the gaps increased steadily from $-1.5 \%$ to $5 \%$. The third phase is from January 2012 to the end of 2014, when the gaps maintained a relatively narrow change between $2.6 \%$ to $5.3 \%$.

Formal statistical analysis can say more precisely what the effect of SPFTZ is on such yield gaps. We split the data period $T$ into two sub-periods: the first period $T_{1}$ is before SPFTZ, from October 8, 2006 to September 30, 2013, and the second period $T_{2}$ is after SPFTZ, from October 1, 2013 to the latest trade day in our study, November 6, 2014. We regress the absolute value of yield gap to time, and see whether there is any trend change since the founding of the SPFTZ.

Table 4. The 3-month onshore/offshore RMB yield gap

\begin{tabular}{|c|c|c|c|c|}
\hline Period & Equation & ESS & Observations & $R$-square \\
\hline$T$ & $\begin{array}{r}Y=1.0872+0.0018 T \\
\quad(0.000) \quad(0.000)\end{array}$ & $2,835.62$ & 2,167 & 0.4850 \\
\hline$T$ & $\begin{array}{c}Y=1.0237+0.0019 T-0.2936 D_{2} \\
(0.000)(0.000)(0.001)\end{array}$ & $2,821.42$ & 2,167 & 0.4876 \\
\hline$T_{1}$ & $\begin{array}{r}Y=1.0031+0.0019 T \\
(0.000) \quad(0.000)\end{array}$ & $2,712.55$ & 1,873 & 0.4195 \\
\hline$T_{2}$ & $\begin{array}{r}Y=12.2046-0.0038 T \\
(0.036) \quad(0.000)\end{array}$ & 40.31 & 294 & 0.4325 \\
\hline \multicolumn{5}{|c|}{ Chow-test $\quad F_{C}=65.3>63.3$} \\
\hline
\end{tabular}

(Note) $Y$ is the absolute value of a 3-month onshore/offshore yield gap, and $T$ is the time trend. ESS stands for Evolutionarily Stable Strategy.

(Source) Authors' computation.

From Table 4, we can make the following observations. (i) The yield gap is different from zero, which means there are still effective capital controls in China. (ii) The start of the SPFTZ has alleviated capital controls. In the whole period there is a time trend for the absolute yield gap to increase (0.0018), but since the start of the SPFTZ this increasing trend has changed to a decreasing trend (-0.0038). The dummy $D_{2}$ is equal to 1 when the time period is $T_{2}$ equals -0.2936 . (iii) There is a regime break on the last day 
of September 2013, when the SPFTZ was founded. If we conduct a Chow Test using the Evolutionarily Stable Strategy (ESS), we can reject the null hypothesis stating that there is no structural change between the two periods.

\section{The Effects on China's Capital Controls}

\section{A. Theoretical foundation}

Our last test on the effects of the SPFTZ employs a Granger causality test based on the Vector Autoregressive (VAR) model. The theoretical basis of such test is quite straightforward, as expressed in Huang (2014). If the capital control were totally effective, we may expect that the expansion of China's monetary supply can only affect transmission internationally through trade channels such as production, exports, and investments instead of financial channels including interest rates and exchange rates. In fact, using data from the period 2000 2012, Huang (2014) finds that the international transmission of the PBoC's balance sheet expansion is more through trade channels than through financial channels.

There are three types of methodologies for the empirical examination of the international transmission mechanisms of monetary policy: simulation experiments, Dynamic Stochastic General Equilibrium (DSGE) models, and the VAR approach. The advantage of a VAR model is that it requires minimal identifying restrictions on the underlying Chinese economic structure, which may differ significantly from the standard theory.

The difference between our work and Huang (2014) lies in that we check the expansion of China's M2 rather than the PBoC's balance sheet. In China's financial system, the commercial banks play an important role in monetary policy practices, especially the so-called Big Four refers to the four state-owned commercial banks, namely Industrial and Commercial Bank of China, Agriculture Bank of China, Bank of China, and China Construction Bank. In Figure 2 we can see that the M2 increase ratio is more stable than that of M0 or M1. Therefore, the PBoC's balance sheet may not be an

${ }^{8}$ See also Christiano et al. (1996), Kim (2001), Mackowiak (2007), among others. 
adequate representation of China's monetary expansion.

\section{B. Data}

We study the relations between China's M2 ratio increase and the interest rates of the US and Japan. The US interest rate is the monthly average of federal fund rates, and the Japanese interest rate is the average of commercial loan rates. The sample period is from August 2008, the beginning month of China's M2 data available, to the latest Japanese exchange rate we can get, August 2014. Altogether there are 37 months of data drawn from the DZH Database, and the data trends are depicted in Figure 7.

\section{Figure 7. Data trends}

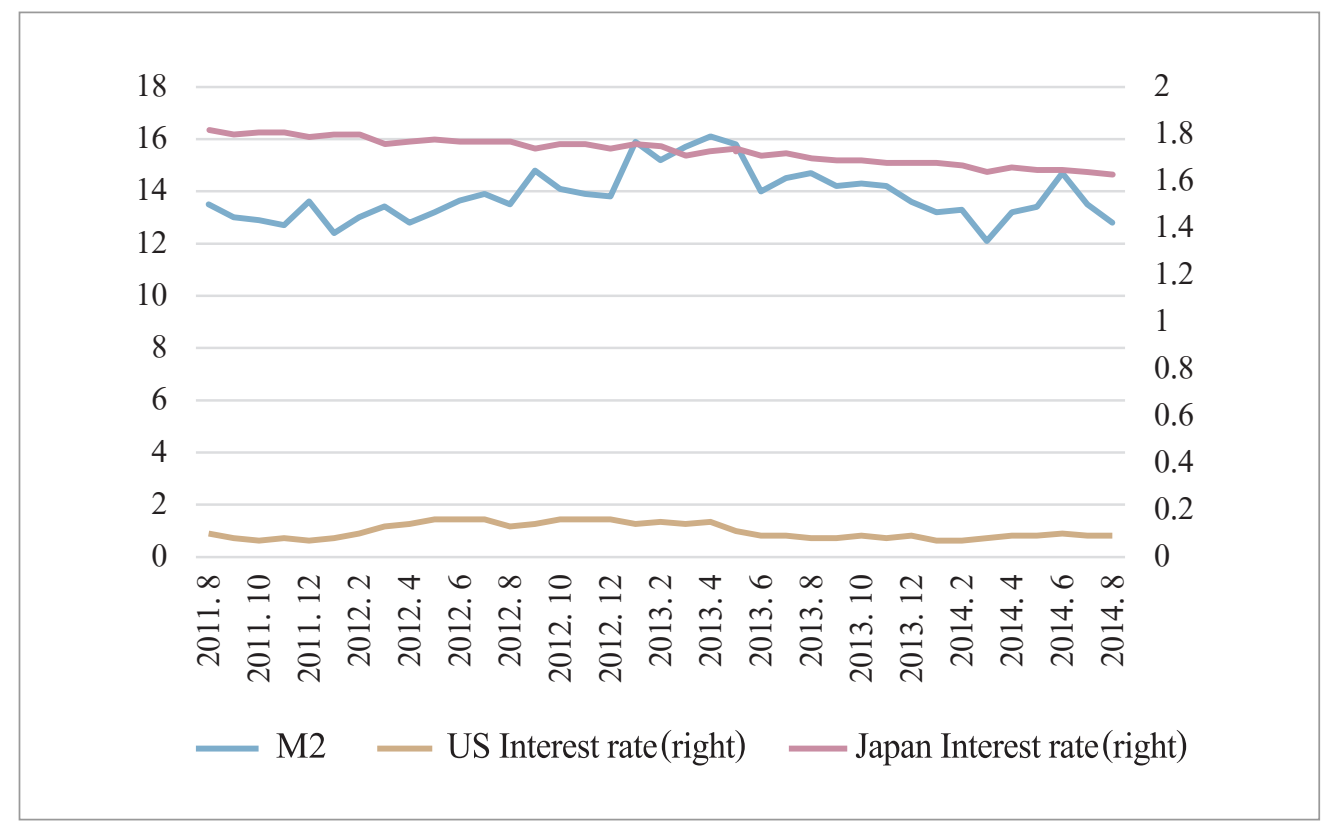

(Source) The DZH Database.

From Figure 7 we can see while the M2 of China expanded monthly at a high speed of $14 \%$ to $16 \%$, the interest rates of both the US and Japan show a decreasing trend. Of course such a decrease may result from the quantitative easing of the US Fed and the Japan's Abenomics financial policy, without much relevance to China's monetary 
expansion. Only by econometric analysis can we say whether there is Granger causality between China's M2 increase and the interest rates of the US and Japan.

\section{Granger causality test}

We analyze a VAR model with three variables: China's M2 increase ratio, the US interest rate, and Japan's interest rate. We make two Granger tests, one using the data between period of August 2011 to September 2013, before the start of the SPFTZ (VAR1); the other uses all of the samples (VAR2). We wish to see whether there is any change in the Granger causalities among the variables. All the necessary tests for time series are fulfilled. Table 5 reports the main test results.

Table 5. Granger Causality Test

\begin{tabular}{|c|c|c|c|}
\hline \multirow{2}{*}{ Equation } & \multirow{2}{*}{ Excluded } & VAR 1 & VAR2 \\
\cline { 2 - 4 } & & Prob $>$ Chi2 & Prob > Chi2 \\
\hline M2 & US Interest rate & $0.055^{*}$ & $0.010^{* * *}$ \\
\hline M2 & Japan Interest rate & $0.045^{* *}$ & 0.364 \\
\hline M2 & all & $0.017^{* *}$ & $0.036^{* *}$ \\
\hline US Interest rate & M2 & $0.092^{*}$ & $0.064^{*}$ \\
\hline
\end{tabular}

(Note) Those variables that are not significant at a $10 \%$ level in both VAR models are omitted. (Source) Authors' computation.

From Table 5 we can see that before the start of the SPFTZ (model VAR1) both interest rates of the US and Japan are Granger causes of China's M2, but the M2 is only the Granger cause of the interest rate in the US at a relatively low significance (9.2\%). After the SPFTZ (model VAR2), the significance of the US interest rate as the Granger cause of China's M2 is higher, from $5.5 \%$ to $1 \%$, so is the reverse causality that China's M2 as the Granger cause of the US interest rate, from $9.2 \%$ to $6.4 \%$. The Chinese financial market is connected to the international market more closely. This is likely because the capital flow in and out of China has become easier after the start of the SPFTZ. 


\section{Concluding Remarks}

In this paper, we discuss preliminary evidence as to the effects of the SPFTZ on China's capital controls. China still maintains relatively rigorous capital controls to keep the exchange rate stable along with monetary policy independence. However, the foreign reserve accumulation and money supply induced has presented China with a dilemma. The start of the SPFTZ is a trial to introduce a middle combination of floating exchange rate and capital account liberalization.

We employ three methods to test the SPFTZ's impact on capital controls: price spread tests between $\mathrm{CNH}$ and CNY, RMB yield gaps between onshore and offshore markets, and Granger causalities among China's money supply and the foreign interest rates. All these tests give consistent results that the impact of capital controls has been lower since the SPFTZ.

It will be more interesting to know how the SPFTZ makes the capital control weaker. As we mentioned in the introduction, the SPFTZ has many policy innovations such as the Free Trade Accounts and Negative List for foreign investment, as well as the trade facilities. Those policies make funds flow in and out of China more freely, make the Chinese financial market more integrated into the international market, and in effect weaken the capital control.

But the current capital account of China is far from free. China has established three more FTZs in Tianjin, Fujian, and Guangdong, but none of them has the Free Trade Accounts policy of the SPFTZ. In order to further open its capital account, China should give the market more room to decide the volume and types of capital flows, both inflow and out-flow. In a recent paper (Yao and Whalley 2015b), we present detailed policy suggestions and future movements on the next stage of China's capital account liberalization.

With the further successful practice of the SPFTZ and more pilot policies replicated in China as a whole, we can anticipate that China's capital control will diminish further in the following decade. China will likely choose a floating exchange rate, free capital account, and independent monetary policy, just as other developed economies do, including the United States, the European Union, and Japan. 


\section{References}

Chen, Hejing and John Whalley. "Are Offshore RMB Arrangements the Basis for a Long-term Exchange Rate System without Convertibility?" China and World Economy 21, no.1 (2013): 26-46.

Christiano, Lawrence J., Martin Eichenbaum and Charles Evans. "The effects of monetary policy shocks: Evidence from the flow of funds." Review of Economics and Statistics 78, no.1 (1996): 16-34.

Huang, Yiping, Peichu Xie and Jiao Wang. "International Transmission of the People's Bank of China's Balance Sheet Expansion.” Asian Economic Policy Review 9 (2014): 276-96.

The Institute of International Finance (IIF). "Capital Flows to Emerging Markets." October 2, 2014. Accessed November 13, 2014. https://www.iif.com/publication/capitalflows/october-2014-capital-flows-emerging-market-economies.

IMF. "Balance of payments and international investment position manual." The $6^{\text {th }}$ edition. 2009. Accessed November 13, 2014. https://www.imf.org/external/pubs/ft/bop/ 2007/pdf/bpm6.pdf.

IMF. “Annual Report on Exchange Arrangements and Exchange Restrictions.” 014. Accessed November 13, 2014. https:/www.imf.org/external/pubs/nft/2014/areaers/ ar2014.pdf.

Kim, Soyoung. "International transmission of U.S. monetary policy shocks: Evidence from VAR's.” Journal of Monetary Economics 48, no.2 (2001): 339-72.

Ma, Guonan. "Efficacy of China's Capital Controls: Evidence from Price and Flow Data." Pacific Economic Review 13, no.1 (2008): 104-23.

Mackowiak, Bartosz. "External shocks, U.S. monetary policy and macroeconomic fluctuations in emerging markets." Journal of Monetary Economics 54, no.8 (2007): 2512-20.

Martin, Michael F. and Wayne M. Morrison. (2008). "China's 'Hot Money’ Problems." CRS Report for Congress. Order Code RS22921. Accessed November 13, 2014, https:// www.fas.org/sgp/crs/row/RS22921.pdf. 
Yao, Daqing and John Whalley. "The China (Shanghai) Pilot Free Trade Zone: Backgrounds, Developments and Preliminary Assessment of Initial Impacts." National Bureau of Economic Research Working Paper, no.20924 (2015a).

Yao, Daqing and John Whalley. “Achieving China’s Capital Account Liberalization Using the Shanghai Free Trade Zone Platform.” (2015b, unpublished manuscript). 